\title{
JURNAL ILMIAH \\ HUBUNGAN TINGKAT PENGETAHUAN DAN SIKAP REMAJA TERHADAP PERILAKU MEROKOK
}

\author{
Laeli Farkhah \\ Sekolah Tinggi Ilmu Kesehatan Kesetiakawanan Sosial Indonesia \\ Email : lalelifarkhah85@gmail.com
}

\begin{abstract}
ABSTRAK
Remaja merupakan fase perkembangan yang memiliki tingkat perubahan (fisik, psikologi, dan sosial) yang signifikan dan merupakan fase pencarian jati diri (Feldman, 2003). Usia anak dan remaja adalah generasi penerus bangsa yang harus dipersiapkan untuk meneruskan perjuangan generasi yang saat ini sedang meminpin. Namun, diperkirakan 43 juta anak-anak Indonesia usia 0-14 tahun terpapar secara tetap pada asap tembakau lingkungan di rumah mereka sendiri (Depkes RI, 2004). Orang tua yang merokok di dalam rumah tentunya tidak hanya menjadi faktor resiko dari berbagai macam penyakit tetapi juga menjadi contoh yang ditiru oleh anak mereka, terutama bagi anak yang menginjak fase remaja.Tujuan dari penelitian ini adalah mengetahui hubungan tingkat pengetahuan dan sikap remaja tentang efek rokok dengan perilaku merokok remaja. Penelitian ini menggunakan metode survey analistik dengan desain study potong lintang (cross sectional) dengan jumlah sampel 20 orang remaja. Hasil penelitian menunjukan bahwa sebanyak 58,3\% remaja usia 17-21 tahun merokok dan ini merupakan persentase tertinggi. Berdasarkan uji chi-square diperoleh 2 variabel yang berhubungan secara bermakna dengan perilaku merokok pada remaja, yaitu tingkat pengetahuan dan sikap remaja yang diperoleh nilai $\mathrm{P}$ Value $0,005(\mathrm{P}$ value $\leq \alpha)$.
\end{abstract}

Kata Kunci : Rokok, Remaja, Pengetahuan, Sikap, dan Perilaku

\begin{abstract}
Adolescence is a developmental phase that has a significant level of change (physical, psychological, and social) and is a phase of self-discovery (Feldman, 2003). The age of children and adolescents is the next generation of the nation that must be prepared to continue the struggle of the generation that is currently leading. However, it is estimated that 43 million Indonesian children aged 0-14 years are regularly exposed to environmental tobacco smoke in their own homes (Depkes RI, 2004). Parents who smoke in the house are certainly not only a risk factor for various diseases but also an example to be imitated by their children, especially for children who are entering the teenage phase. with adolescent smoking behavior. This study uses an analytical survey method with a cross-sectional study design with a sample of 20 teenagers. The results showed that as many as $58.3 \%$ of adolescents aged 17-21 years smoked and this was the highest percentage. Based on the chisquare test, there were 2 variables that were significantly related to smoking behavior in adolescents, namely the level of knowledge and attitudes of adolescents, which obtained a $P$ value of 0.005 ( $P$ value ).
\end{abstract}

Keywords: Cigarettes, Adolescents, Knowledge, Attitudes, and Behaviors 


\section{PENDAHULUAN}

Indonesia merupakan salah satu negara berkembang yang memiliki tingkat konsumsi dan produksi rokok yang tinggi. Bahkan, variasi produk dan harga rokok di indonesia telah menempatkan indonesia menjadi salah satu produsen sekaligus konsumen rokok terbesar di dunia (Pusat Promkes, 2002). Berdasarkan data Global Tobacco Control Report tahun 2008, 2/3 perokok tinggal di 10 negara dan Indonesia menempati urutan ketiga jumlah perokok terbanyak di dunia, setelah Cina dan India (WHO, 2008).

Saat ini, produk rokok sudah menyebar luas di seluruh dunia dengan jumlah konsumen yang terus meningkat. Pada tahun 2005, diperkirakan 1,6 milyar penduduk dunia adalah perokok, miningkat dari 1,1 milyar perokok pada tahun 2000 (Crofton, 2009).

Kini akibat meningkatnya jumlah perokok di dunia, pada tahun 2006, setiap 6 detik terjadi 1 kematian akibat rokok setara dengan 4,5 juta jiwa dalam 1 tahun. Diduga hingga menjelang tahun 2030 kematian akibat merokok akan mencapai 10 juta orang per tahunnya dan diperkirakan $70 \%$ diantaranya terjadi di negara-negara berkembang (WHO 2008).

Rokok teleh menjadi penyebab kematian di dunia yang terus menikat jumlah konsumennya serta jumlah kematian yang ditimbulkannya. "Tobacco is the only legally available consumer product which kill people when it is entirely used as intended." (The Oxford Medical Companion, 1994 dalam Mackay, 2002).

Kalimat di atas menunjukan bahwa tembakau merupakan produk konsumsi yang dapat menyebabkan kematian, bahkan ketika produk ini digunakan sesuai anjuran produsennya (tidak disalahgunakan).Kalimat ini juga menegaskan bahwa rokok, sebagai produk utama hasil olahan tembakau, merupakan alat penyebab kematian yang diproduksi dan dijual secara bebas.

$$
\text { Remaja merupakan fase }
$$
perkembangan yang memiliki tingkat perubahan (fisik, psikologi, dan sosial) yang signifikan dan merupakan fase pencarian jati diri (Feldman, 2003).

Usia anak dan remaja adalah generasi penerus bangsa yang harus dipersiapkan untuk meneruskan perjuangan generasi yang saat ini sedang meminpin. Namun, diperkirakan 43 juta anak-anak Indonesia usia 0-14 tahun terpapar secara tetap pada asap tembakau lingkungan di rumah mereka sendiri (Depkes RI, 2004).

Orang tua yang merokok di dalam rumah tentunya tidak hanya menjadi faktor resiko dari berbagai macam penyakit tetapi juga menjadi contoh yang ditiru oleh anak mereka, terutama bagi anak yang menginjak fase remaja.

Global Youth Tobacco Survey tahun 2006 menunjukan bahwa prevalensi perokok barusia 13-15 tahun adalah $24,5 \%$ pada pria dan $2,3 \%$ pada perempuan muda di provinsi Sumatra dan Jawa. Meskipun persentase ini kecil, namun dampak yang ditimbulkan sangat besar karena usia 13-15 merupakan bagian dari generasi penerus bangsa. Jumlah ini merupakan keberhasilan dari promosi produsen rokok pada remaja muda Indonesia. Berbagai cara yang dilakukan, diantaranya menggunakan pesan yang menyesatkan (mild, light, dll), menjadi sponsor kegiatan remaja (olahraga, film, dll), menampilkan iklan 
yang menarik hingga menawarkan sampel rokok gratis untuk remaja (WHO, 2008).

Semua itu dilakukan agar semakin banyak remaja yang menjadi konsumen setia di masa depan. Hal ini sesuai dengan dokumentasi internal sebuah pabrik rokok pada tahun 1981: "Generasi muda sekarang adalah konsumen setia (rokok) yang potensial di masa depan dan sebagian besar perokok mulai merokok saat mereka berusia remaja" (mpower: Upaya pengendalian konsumen tembakau, WHO 2008).

Penelitian terdahulu menunjukkan bahwa miskinnya pengetahuan atau tidak adanya keyakinan terhadap akibat-akibat merokok dapat menyulitkan individu untuk membangun suatu sikap atau akan memiliki sikap yang cenderung lemah terhadap rokok (Crhistanto, 2004).

Selanjutnya,Notoatmodjo

(2003)

dalam penelitiannya menyatakan bahwa pengetahuan (knowledge) memegang pengaruh yang besar di dalam perilaku seseorang dan apabila pernyataan ini dikaitkan dengan perilaku merokok, maka pengetahuan seseorang tentang rokok akan menentukan seseorang untuk menjadi perokok atau tidak. Akan tetapi, pada kenyataannya pengaruh iklan tentang rokok sering menimbulkan pengetahuan yang salah tentang rokok.

Pembentukan pengetahuan tentang rokok dapat terbentuk dari adanya penginderaan terhadap iklan-iklan rokok yang banyak tertampang di semua tempat mulai dari tempat umum yang bebentuk baliho sampai ke dalam rumah melalui iklan yang ditayangkan di televisi yang biasanya cenderung membentuk pengetahuan yang salah tentang rokok karena jargon iklan rokok sering dirancang sesuai dengan karakteristik remaja yang menginginkan kebebasan, independensi, dan pemberontakan pada norma-norma (Wullur, 2008).

Efek merokok yang langsung dirasakan oleh perokok adalah meningkatnya denyut jantung, sesak nafas, menurunnya tingkat kesehatan dan kinerja, serta berkurangnya daya kecap dan penciuman. Sedangkan efek yang bersifat jangka panjang dari merokok adalah timbulnya noda pada gigi, jerawat dan masalah-masalah kulit lainnya, serta penyakit-penyakit yang bisa muncul diberbagai sistem tubuh.

Pengetahuan yang salah tentang rokok ini selanjutnya akan mendorong terbentuknya sikap yang salah tentang rokok dan pada akhirnya terjadi proses aplikasi dimana seseorang akan menjadi perokok. Hasil penelitian yang dilakukan oleh Pattinasarany (2004) dalam penelitiannya menyebutkan bahwa terdapat hubungan yang signifikan antara sikap terhadap merokok dengan perilaku merokok remaja. Jika dilihat dari perspektif budaya, terdapat adanya budaya lokal yang dapat menimbulkan sikap yang salah tentang rokok. Sebagai contoh. Pada budaya Jawa didapatkan bahwa pada saat transisi ke usia dewasa , biasanya pada saat anak dikhitan, dinyatakan dengan orang tua memberikan rokok pada anaknya.

Dalam upaya menganalisis hubungan tingkat pengetahuan dan sikap remaja tentang efek rokok dengan perilaku merokok remaja, peneliti bermaksud melakukan penelitian di RT 09 Bojong Raya Jakarta Barat agar dapat dilakukan tindakan nyata terhadap hubungan-hubungan tersebut guna untuk menurunkan kebiasaan merokok di kalangan remaja di RT 09 Bojong Raya Jakarta Barat. RT 09 dipilih sebagai tempat penelitian dengan alasan terdapat 
banyak remaja yang melakukan aktifitas merokok (Anonim:wawancara dengan salah satu remajawarga RT 09).

\section{METODE PENELITIAN}

Desain penelitian ini menggunakan metode survei dengan pendekatan cross-sectional dan merupakan studi deskriftif analistik jenis kolerasi. Yaitu untuk mengetahui apakah ada hubungan antara tingkat pengetahuan dan sikap remaja tentang efek rokok dengan perilaku merokok remaja.

Populasi pada penelitian ini meliputi sebagian anak remaja di RT RT 09 Bojong Raya Jakarta Barat. Dalam hal ini jumlah populasi yang akan diteliti 20 responden. Sampel adalah bagian dari populasi yang akan dipilih dengan cara tertentu, sehingga dianggap mewakili populasi yang akan diteliti. Sampel pada penelitian ini merupakan sampel jenuh, sehingga jumlah sampel sama dengan jumlah populasi yaitu 20 responden.

Pengumpulan data pada penelitian ini dengan cara menelusuri data sekunder dan dengan menyebarkan kuisioner kepada responden. Alat yang akan digunakan berupa data sekunder dan kuesioner, yang mencangkup:

Sebelum kuisioner dibagikan kepada responden diadakan uji validitas dan reliabilitas terlebih dahulu. Untuk uji validitas setiap butir instrumen, diadakan pengujian dengan cara menganalisis hubungan antara skor tiap butir dengan skor total butir. Rumus yang digunakan adalah rumus Korelasi Product Moment sederhana (Widodo, 2004),

Data di kumpulkan dengan menggunakan alat bantu kuesioner dan berbagai alat tulis (pulpen, pensil, dan penghapus). Pengolahan data pada penelitian ini melalui tahapan : coding, editing, scoring, entry dan cleaning.

\section{HASIL PENELITIAN Karakteristik responden}

Dari hasil analisa data menunjukkan bahwa, karakteristik usia, dari 20 responden terdapat 8 responden berusia 12-16 tahun ( $40,0 \%$ ), dan dari 20 responden terdapat pula 12 responden yang berusia 17-21 tahun ( 60,0 \% ). Berdasarkan Karakteristik jenis kelamin, dari 20 responden terdapat 9 responden perempuan ( $45,0 \%$ ), sedangkan yang laki-laki dari 20 responden terdapat 11 responden ( 55,0 \% ). Dan dari kerakteristik pendidikan, dari 20 responden terdapat 4 responden yang berpendidikkan SD ( 20,0 \% ), sedangkan yang berpendidikan SMP dan SMA kaduanya terdapat 8 responden( $40,0 \%$ )

\section{Karakteristik responden berdasarkan pengetahuan}

Dari hasil analisa data menunjukan bahwa, dari 20 responden dapat diketahui bahwa terdapat 9 responden yang memiliki pengetahuan yang baik ( 45,0\%), sedangkan dari 20 responden yang memiliki pengetahuan yang tidak baik terdapat 11 responden $(55,0 \%)$.

\section{Karakteristik responden berdasarkan sikap}

Dari hasil analisa data menunjukan bahwa, dapat diketahui bahwa sikap remaja yang baik lebih rendah dari sikap yang tidak baik, sikap yang baik dari dari 20 responden terdapat 9 responden ( 45,0 \% ) sedangkan sikap yang tidak baik dari 20 responden terdapat 11 responden $(55,0 \%)$. 


\section{Karakteristik responden berdasarkan perilaku}

Dari hasil analisa pada tabel dinton menunjukan bahwa, dari 20 respo 35 terdapat persemaan dalam jumlah frekuensi maupun persentase masingmasing terdapat 10 responden dengan sikap yang baik,dan 10 responden dengan sikap yang tidak baikmasing-masing ( $50,0 \%)$.

\section{PEMBAHASAN}

\section{Tingkat Pengetahuan Remaja}

Variabel independen pengetahuan remaja dikelompokan menjadi 2 kategori, yaitu: baik, dan tidak baik. Dari hasil analisa data diperoleh $45,0 \%$ remaja yang memiliki pengetahuan yang baik, dan 55,0 $\%$ remaja yang memiliki pengetahuan yang tidak baik.

Hasil penelitian ini sesuai dengan penelitian yang dilakukan oleh Agustina Kurniasih (2008), dengan judul "Perilaku Merokok Siswa SLTP (remaja) di Kota Bekasi", terhadap 35 responden diperoleh hasil 47,0 \% remaja (siswa) memiliki pengetahuan yang baik, dan 53,0 \% remaja (siswa) memiliki pengetahuan yang tidak baik.

\section{Sikap Remaja}

Variabel independen sikap remaja dikelompokan menjadi 2 kategori, yaitu: baik, dan tidak baik. Dari hasil analisa data diperoleh $45,0 \%$ remaja yang memiliki pengetahuan yang baik, dan 55,0 $\%$ remaja yang memiliki pengetahuan yang tidak baik.

Hasil penelitian ini sesuai dengan penelitian yang dilakukan oleh Ratna Yunita (2007), dengan judul "Gambaran Perilaku Merokok dan Faktor-Faktor yang Berhubungan pada Pelajar SLTP di Depok", yang diperoleh hasil 44,0 \% remaja (siswa) memiliki pengetahuan yang baik, dan 56,0 \% remaja (siswa) memiliki pengetahuan yang tidak baik.

\section{KESIMPULAN}

Terdapat hubungan yang bermakna antara tingkat pengetahuan, jika remaja yang memiliki tingkat pengetahuan yang baik dengan prilaku merokok remaja. RT 09 Bojong Raya Jakarta Barat. Hal ini ditandai dengan nilai $P$ value $=0,005$.

Terdapat hubungan yang bermakna antara sikap,bila remaja memiliki sikap yang baik dengan perilaku merokok remaja. Di RT 09 Bojong Raya Jakarta Barat. Hal ini juga ditandai dengan nilai $P$ value $=0,005$.

\section{SARAN}

Diharapkan bagi seluruh pemuda yang tergabung dalam himpunan pemuda karang taruna maupun remaja masjid terkhusus di wilayah Rt 09 Bojong Raya Jakarta Barat agar kiranya mampu bersinergi dengan para tega kesehatan (Puskesmas) maupun para kader dalam melakukan sosialisasi rutin sebagai agenda/program kerjanya terkait tentang bahaya dari merokok.

\section{DAFTAR PUSTAKA}

Ahsan, Abdillah. 2009. Dampak Tembakau dan Pengendaliannya di Indonesia. Jakarta: hasil kerjasamaWHO dan Lembaga Demografi FE UI.

Aji, Kandi Santi. 2003. Gambaran Perilaku Merokok dan FaktorFaktor yang Berhubungan pada Pelajar SLTPN Di Depok Tahun 2002. Skripsi. Depok: Fakultas Kesehatan Masyarakat, Universitas Indonesia. 
Crofton, John dan David Simpson. 2009.

Tembakau Ancaman Global.

Jakarta: PT Elex Media

Komputindo.

Dariyo, Agoes. 2004. Psikologi Perkembangan Remaja. Jakarta: Ghalia Indonesia.

Depertemen perindustrian. 2009. RoadmapIndustri Pengolahan

Tembakau. Jakarta: Direktorat Jenderal Agro dan Kimia, Dep. Perindustrian.

Departemen Kesehatan RI. 2004. Fakta Tembakau Indonesia: Data Empiris untuk Strategi Nasional Penanggulangan Masalah Tembakau. Jakarta: Depkes RI.

Feldman, Robert S. 2003. Essentials of Understanding Psychology. New York: McGraw-Hill.

Hendarto, Jenniwal M. 2005. Penggunaan Media di Kalangan Remaja. Jurnal Thesis SeptemberDesember 2005. Skripsi. Depok: Fakultas Ilmu Sosial dan Ilmu Politik, Universitas Indonesia.

Iqbal, Muhamad Fariz. 2008. Perilaku Merokok Remaja di Lingkungan RW 22 Kelurahan Sukatani, Kecamatan Cimanggis, Depok Tahun 2008. Skripsi. Depok: Fakultas Kesehatan Masyarakat, Universitas Indonesia.

Kurniasih, Agustina. 2008. Fakto-Faktor yang Berhubungan dengan Perilaku Merokok Siswa SLTP di Bekasi Tahun 2008. Skripsi.
Depok: Fakultas Kesehatan Masyrakat, Universitas Indonesia. Mackay, Judith dan Michael Eriksen. 2002. The Tobacco Atlas. Geneva: WHO.

Notoatmodjo, Soekidjo. 2002. Metodologi Penelitian Kesehatan. Jakarta: PT. Rineka Cipta.

Notoatmodjo, Soekidjo. 2003. Pendidikan dan Perilaku Kesehatan. Jakarta: PT Rineka Cipta.

Notoatmodjo, Soekidjo. 2005. Promosi Kesehatan: Teori dan Aplikasi. Jakarta: PT Rineka Cipta.

Pusat Data dan Informasi Departemen Kesehatan RI. 2009. Prifil Kesehatan Indonesia 2008. Jakarta: Depkes RI.

Pusat Penelitian Kesehatan Universitas Indonesia. 2010. Lembar Fakta: Rokok, Kemiskinan dan Generasi yang Hilang: Kepentingan Jangka Panjang. Depok: PPK UI.

Pusat Promosi Kesehatan Departemen Kesehatan RI. 2002. Kawasan Tanpa Rokok. Jakarta: Depkes RI. Yunita, Ratna. 2007. Hubungan Antara Perilaku Merokok Orang Tua dengan Perilaku Merokok Siswa SMP di Kota Bogor, Tahun 2007.Tesis. Depok: Fakultas Kesehatan Masyrakat, Universitas Indonesia.

Yusuf, Syamsul. Februari 2009. Psikologi Perkembangan Anak dan Remaja. Bandung: PT Remaja Rosdakarya. 